https://doi.org/10.15407/ujpe66.9.819

M.V. GUTNYK, E.E. TVERYTNYKOVA

National Technical University "Kharkiv Polytechnic Institute"

(2, Kurpuchova Str., Kharkiv 61002, Ukraine; e-mail: maryna.gutnyk@khpi.edu.ua)

\title{
THE PROFESSOR G. DE-METZ'S CONTRIBUTION TO THE DEVELOPMENT OF PHYSICAL SCIENCE IN UKRAINE
}

\begin{abstract}
The contribution of Professor Georgy De-Metz to the development of physical science in Ukraine is highlighted. The information about the childhood of the future scientist is given and his formation as a scientist is shown. He was extensively involved in physics under the guidance of F. Shvedov and M. Umov. The head of his master's thesis was Professor A. Kundt. After the publication of the discovery of X-rays by Roentgen, $G$. De-Metz not only repeated the experiments of the German colleague, but also put new ones. In particular, he investigated the influence of various physical factors on obtaining the clear photographs of this radiation. The scientist managed to make clear pictures of frogs with an image of the internal organs. He also explored the possibility of using X-rays in medicine. In the early twentieth century, he published his first major work on radioactivity "Doctrine of the radioactivity and radioactive substances", in which the scientist described the physical basics of radioactivity in detail. The researcher examined the radium content in water and flora from the pond of the Kyiv Botanical garden. Using the results of the studies G. De-Metz concluded that some types of living tissue were able to absorb and even concentrate radium from water and the environment. In his work "Radioactivity and the structure of matter," not only a historical review of the development of the doctrine of radioactivity was made, but also the new experimental works of the author were represented. He analyzed 68 various minerals of uranium. G. De-Metz described the picture of the geographical distribution of radioactive minerals and identified the richest deposits of uranium ore at that time. In addition to his scientific work, the scientist was a well-known methodist. It was he who, in the 1920s, developed a method of teaching physics in institutes of Ukraine. It is reported that the scientist in a different period of time was the head of the physical department at various institutions of higher education. Moreover, he was even the Rector of the St. Volodymyr University, Kyiv Polytechnic Institute, and Kuban University.

Keywords: Georgy De-Metz, physical science, Ukraine, X-rays, medical physics, teaching methodology.
\end{abstract}

\section{Introduction}

Among the pleiad of outstanding physicists (M. Avenarius, F. Shvedov, M. Umov, Y. Kosonogov, O. Holdman, A. Zhelekhovskyi, M. Pilchikov, and others) of the late XIX and mid-XX centuries, a prominent place belongs to Georgy De-Metz. The sci-

(C) M.V. GUTNYK, E.E. TVERYTNYKOVA, 2021

ISSN 2071-0194. Ukr. J. Phys. 2021. Vol. 66, No. 9 entist was a unique researcher: he headed several departments and even was the Rector of three higher education institutions, and he stood at the origins of the Ukrainian Academy of Sciences. Among the leading areas of his scientific search were innovative researches in the field of medical physics. The Professor also developed a method of teaching physics in institutes. 


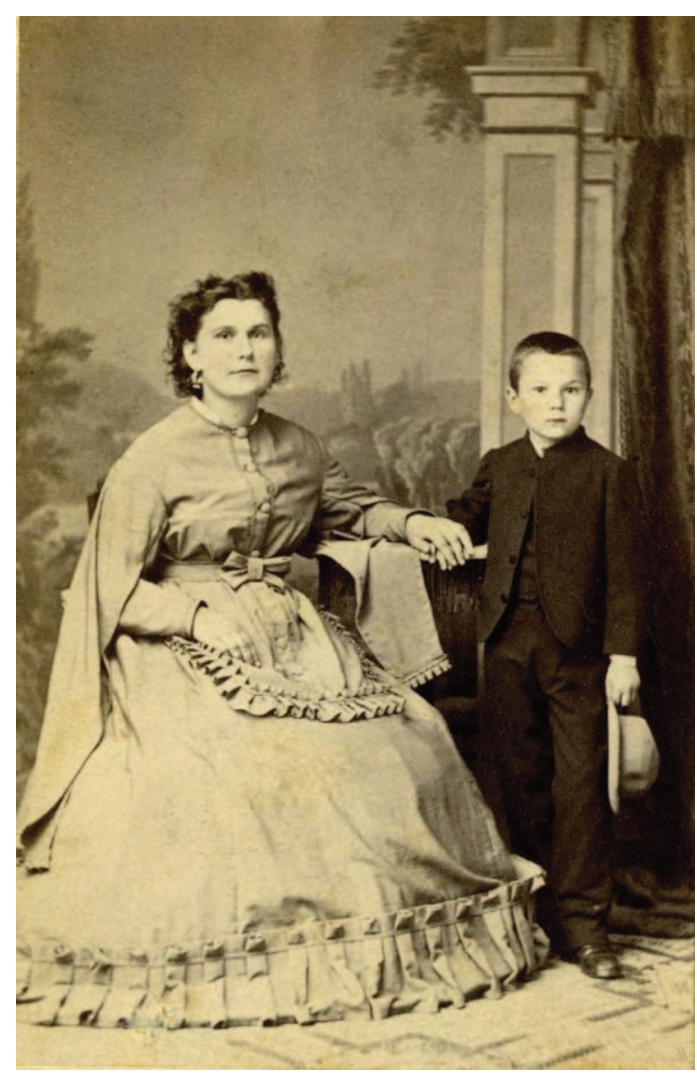

Photo 1. G. De-Metz with his mother, 1867

G. De Metz actively developed the physical studies that he had begun in Germany under the guidance of Professor A. Kundt. The scientist, like W.C. Roentgen and I. Pulyui, was engaged in invisible radiation, the so-called X-rays. However, the name of G. DeMetz because of political problems that plagued Ukraine was unjustifiably forgotten. There are only brief references to G. De-Metz's figure in the Brockhaus and Efron Dictionary [1, p. 177-178] and, in fact, the same information on universities' websites [2-4], where he worked or which he headed.

His scientific background has been studied by biologists [5], educators [6], physicists [7], and even dentists [8]. Some of the publications $[9,10]$ contain minor inaccuracies, in particular, in the date of birth. In addition, they did not cover the entire scientific path of the scientist, but only individual periods, which makes it impossible to establish the scale of the figure of the scientist. Publication [11] is more complete in the biographical aspect, but does not emphasize G. De-Metz's achievement in physical science.

\section{Main Text}

The future scientist was born on May 9 (21), 1861 in Odessa, in the family of Belgian engineer Georges De-Metz and noblewoman Olga Travina (see Photo 1). When Yurko (as he was called in his family) became two years old, his father went bankrupt and left the Russian empire in a search for new financial opportunities. The caring for the son completely had fallen upon his mother [12].

In August 1868, George began to study in the best then-boarding house in Odessa, headed by A. Knori. He studied arithmetic, the basics of German and French, studied Russian and ancient languages - Latin, Greek [12]. The filling of the educational programs of the boarding school was quite diverse and often did not correspond to the age of the students, so the knowledge was superficial. Sometimes, the material was simply cramming. For the smallest disobedience, the students were even beaten. G. De-Metz himself was often stayed without evening tea and sweets. When Georgy was transferred to the 6th grade, due to the reforms of the then Minister of Education, Count D. Tolstoy, the private boarding schools and gymnasia lost the right to provide "matriculation certificates", so this boarding house was closed. Georgy tried to enter the 3rd Gymnasium of Odessa, but failed the exams, because, as it turned out later, the training in this board in all subjects was weak. It should be noted that, during the spring months of 1875, Georgy studied arithmetic with Theophany Vasilevskiy, later with Mr. Maliovanniy. These teachers are easily and coherently taught to understand mathematics. As mentioned by Georgy, much for his intellectual development was made his baptized - Earl Eugene Gagarin.

Subsequently, he continued his studies at the Alexander Men'sgrammar school in Nikolaev, which he graduated in 1881 with a gold medal. It should be noted that the Alexander Men'sgrammar school was planned to be transformed into a Polytechnic Institute, for which considerable subsidies from the naval department would be allocated. For training purposes, physical, meteorological, and numismatic offices were equipped, and a chemical laboratory was established.

In the fall of 1881, G. De-Metz entered the mathematical Department of the Physics and Mathematics Faculty of Novorossiysk (Odessa) University. The sci- 
entist enthusiastically described his time at the university. He was engaged in physics under the direction of F. Shvedov and M. Umov thoroughly. The young scientist was interested in B. Franklin's experiments on the creation of a lightning rod, participated in a physical club. In December 1883, he made his first public report on the origin of geometric axioms. In some time, he made a report "The Doctrine of the Lobachevski Space", which provoked considerable debates [13, p. 271-281]. G. De-Metz's diploma study "Essays on the Abnormal Dispersion of Light in its Facts and Theories from the Beginning of the Question to Our Days" was awarded a gold medal. This work consisted of two parts. The first one, despite being unfinished, was devoted to experimental questions, the second - to the theoretical substantiation of the scientific problem. The author provided a fairly complete list of literature of 104 titles. He investigated thoroughly and in details the history of the question including the work (1871) by A. Kundt and consistently considered the anomalous dispersion in solids, liquids, and gases [9, p. 170].

After the graduation from the University, since September 22, 1885 at the request of the Faculty of Mathematics and Physics, G. De-Metz was admitted to the post of the second laboratory assistant of the physical cabinet. The existed practice of the training of professors assumed the scientific internships. Every year, the Ministry of Public Education has appropriated 50,000 karb., which distributed according to the needs of the University Councils. Because such funds not always were used rationally, in 1884 the Ministry put forward a number of requirements. In particular, the applicants had to have high enough marks in the certificate, and, in a special subject and related ones excellent, they must to speak German or French at the level of reading books in the relevant specialty, to have perfect morality, to be able to formulate their thoughts correctly and freely, to demonstrate other qualifications necessary for the teacher, and also to have good health [14].

On November 11, 1885, the Scientific Committee of the Ministry of Public Education considered the question of the possibility to provide for G. De-Metz a job place for two years at the Novorossiysk University to prepare for the professorship at the Department of Physics. In the candidate's, file there was a note from the Dean of the Faculty, Professor F. Shvedov and Professor M. Umov, in which they characterized the graduate and assessed his ability and aptitude for scientific work. It was noted that the applicant during his studies at the university "showed great dedication and ability to take classes in physics, which was embodied in the continuous work in the physical rooms and reading special articles and works". It was noted that this internship would be useful in the solution of the problem which was started at his diploma project. The decision of the Ministry was positivem and the internship of a young scientist began on November 15, 1885 [9, p. 170].

G. De-Metz entered the Institute of Physics at the University of Strasbourg, where he conducted researches on various issues of physics under the guidance of Professor A. Kundt. At one time, among the students of A. Kundt were such famous physicists as W.C. Roentgen and I. Pulyui. In addition, later, G. De-Metz used the I. Pulyui's device for measuring the mechanical equivalent of heat to demonstrate physical experiments $[11$, p. $6 ; 15$, p. 18].

In Strasbourg, Georgy De-Metz managed not only to work on putted tasks, but also to perform an experimental study "About double refraction in rotating layers of fluid", which later became the basis for his master thesis. In particular he has enhanced the methodology for the study of double refraction in liquids created by J.C. Maxwell. The scientist investigated this phenomenon in 16 fluids [16, p. 943953]. On October 12, 1888, Georgy successfully compiled the master's oral examination, and the public defense of master thesis "Research of mechanical properties of oils and colloids" (April 8, 1888) was approved by the Council of the University with a master's degree in physics. Thus, he got possibility to read courses on measuring in physics and higher optics. In particular, he lectured on "The electric current theory", "The light distribution in crystals", "Measuring instruments" and, as a special course, "Physics of partial forces" [17; 9, p. 171].

The year 1889 proved to be a landmark for a young scientist: Georgy married to the daughter of Staff Captain - Sarah Kraft (1863-1941), with whom he had been familiar since 1882 as he was a student. The couple had three children - Margarita (1890-1972), Tatiana (1895-1941) and George (1896-1920) (see Photo 2).

In December 1889-January 1890, G. De-Metz was sent to St.Petersburg as a member of the 8th Congress of Naturalists and Physicians, where he 


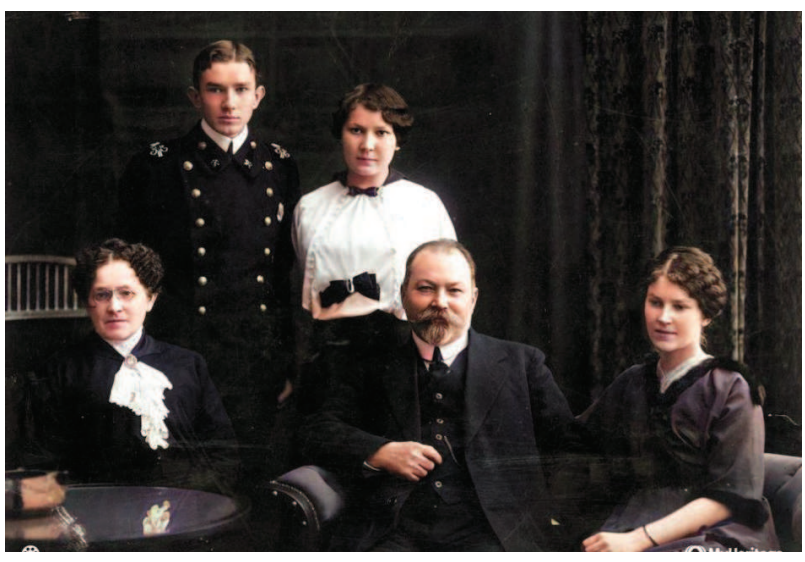

Photo 2. Family of De-Metz, 1917 [colorized by authors]

made a report on the Section of Physics "About the compressibility of oils and colloids". The scientist established the coefficient of compression for colloidal solutions and noted that the mechanical deformation temporarily changes the elasticity of the micellar structure, which is accompanied by a temporary double refraction in the colloids [18, p. 288].

On August 20, 1890 he was appointed at the position of Private-docent, and on April 5, 1891, he applied for the admission to the thesis "About the absolute compressibility of mercury and glass" defense in order to obtain a Doctor of Physics degree. After the public defense of the work on May 31, 1891, the University Council approved a scientist in the degree of Doctor of Physics [19, p. 328]. Already in June 1891, the Dean of the faculty proposed to transfer G. DeMetz to the post of extraordinary professor. That is, in a rather short period of time, only five years after the graduation, Georgy has already established himself as an independent researcher and got the professorship [9, p. 171].

By the invitation of the Rector of St. Volodymyr Kyiv University, the scientist moved to Kyiv. At this University since January 29, 1892, he held the position of Extraordinary Professor, and, since 1896 an Ordinary Professor at the Department of Physics. The predecessor of G. De-Metz, M. Avenarius created the first laboratory of experimental physics in Ukraine, as well as a physical laboratory workshop for students. M. Avenarius's work was greatly expanded by G. De Metz, because, in addition to lecturing and practicing with students, he was the one who took care of the physical laboratory and cre- ated the Museum of Physical Devices [11, p. 6; 20, p. $78-82]$.

The defining characteristic of G. De-Metz activity was the publication of articles on topical issues in physics, which was intensively developed at the turn of the XIX and XX centuries. At this time, his articles "Modern views of electricity" [21], "On the current state of color photography" [22], "On Tesla's experiments with alternating currents" [23] were published. In these publications, the experiments in physics were popularized, the equipment needed for the experiments was described; the style of presented material was quite easy to read and has piqued the interest of readers in researches. Most publications of that time were read in the meetings of the Kyiv branch of the Russian technical society (RTS), where, during the years 1903-1906, the scientist headed the photographic department (was doing research on color photography, and was interested in cinematography). In 1905-1918, he was the Chairman of the Kyiv branch of the RTS, succeeded M. Bunge [17, p. 105].

In 1896, after the publication of W.C. Roentgen on the discovery of X-rays, G. De Metz remade the experiment in Kyiv and studied the effect of these rays on the various animate and inanimate objects. Since that time, the leading research subject of the Professor was the study of natural radioactivity of living organisms and the effect of ionizing radiation on living creatures. He demonstrated X-rays in the lectures. In March 1896, he published the article "Photos inside the Crookes' tube" [24], where he considered the nature of X-rays and their ability to penetrate a variety of objects, including tissues of living organisms. At this, the scientist didn't stop and investigated the effect of magnetic field on the penetrating ability of X-rays. The results of the studies in 1897, Georgy published in the article "The Effect of magnet on Xrays" [25]. In addition, G. De-Metz examined the influence of various physical factors on the obtaining of clear photos from this radiation. The scientist managed to make clear pictures of frogs with an image of the internal organs. In the publication "X-rays and field of their application in medicine" [26], he confirmed the study of I. Pulyui that X-rays can be used for the diagnostics of internal organs and the human treatment.

On August 1900, he took part in the International Congress of Physicists in Paris. G. De-Metz was im- 
pressed by the radioactive drug in a glass jar showed by the Rapporteur of P. Curie [11, p. 7].

In 1905, he published his first major work on radioactivity "The doctrine on the radioactivity and radioactive substances" [27] in which he described, in detail, the physical basis of radioactivity. This work was so relevant that book was reprinted in 1925, 1926, 1935. In addition G. De-Metz conducted research on the content of radium in the water and flora from the pond of the Kyiv Botanical garden. First and foremost, he was interested in the accumulation of radium by duckweed (Lemna minor L.). Analyzing the results of the research, he concluded that some types of living tissue were able to absorb and even concentrate radium from water and the environment. Based on the research, the scientist made a reasonable conclusion that the change in the radioactivity of a particular organism depends on the conditions of its existence [28, p. 70; 29, p. 181-185].

In 1931, he published another fundamental work in this direction - "Radioactivity and the structure of matter" [30], which presented a historical review of the development of the doctrine of radioactivity, generalized knowledge about radioactivity and radioactive substances, historical discoveries of W.C. Roentgen, A. Becquerel, M. Sklodowska-Curie and P. Curie, I. Pulyui, M. Pilchikov, G. Schmidt, E. Rutherford, and other prominent scientists. The monograph described the new, at that time, experimental works of the author and his contemporaries S. Meyer, E. Swidler, D. Bartelio, Kh. Patterson, T. Tommasin, A. Nodon, etc. In this work, G. De-Metz described the well-known radioactive minerals, made the conclusion that radioactivity is closely associated with uranium and thorium, therefore, the search for rich sources of radioactive substances should be directed to uranium and thorium ores and minerals. He analyzed 68 different uranium minerals. This abundance, in his opinion, testified to the important role of uranium in the formation and existence of the Globe. G. De-Metz described the picture of the geographical distribution of radioactive minerals and the rich deposits of uranium ores that were identified at that time [28].

From November 1896, G. De-Metz took an active role in the Special Committee, which was engaged in the organization of the Kyiv Polytechnic Institute. The editorial committee chaired by Professor S. Solsky was created to develop the status and

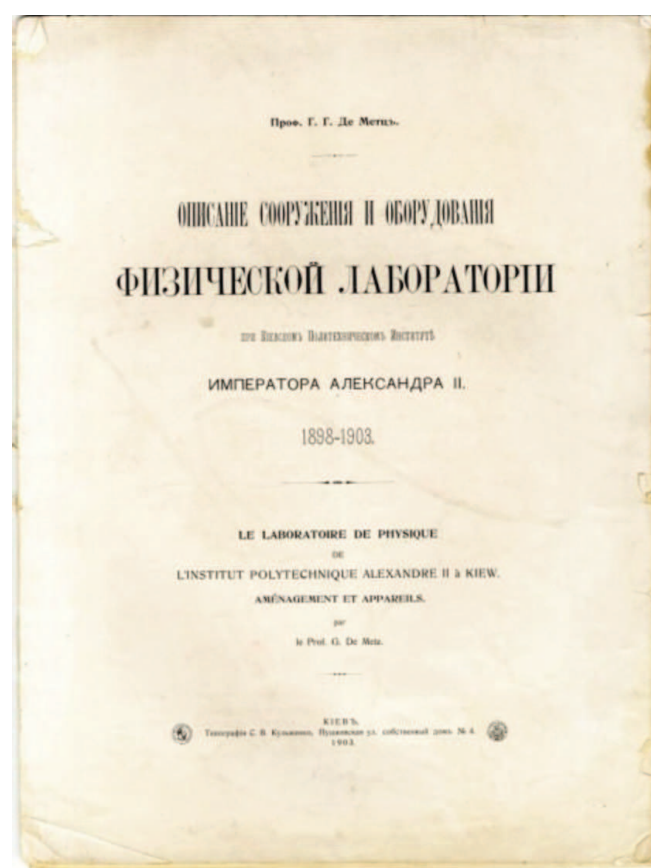

Photo 3. The cover page of the book "Description of construction and equipment of Physical laboratory at the Kyiv Polytechnic Institute", Kyiv 1903 [from 36]

staffing, curricula and programs. Professor G. DeMetz was also included in it. He also was a member of the Construction Commission, chaired by Professor M. Samofalov [31, p. 4-5]. From August 15, 1898, G. De-Metz was appointed to the Kyiv Polytechnic Institute as a full professor at the Department of Physics with the preservation of a position at the University of St. Volodymyr [32, p. 35].

It was Professor G. De-Metz who was responsible for the creation of a physical laboratory and a large physical audience; the architect I. Kittner had to rework the physical lab projects several times, taking the requirements of the customer into account. The towers in the first building were built to carry out projects that required heights, and balconies were designed to accommodate appliances that needed an open horizon. The $42 \mathrm{~m}$ long corridor was designed so that some physical experiments could be performed using the length of the room [33]. The number of rooms and apparatus of the physical laboratory were determined on the basis that the demonstration of the experiments at the lectures did not interfere with the practical training, as well as to conduct scientific researches. In the laboratory, the scientist tried 


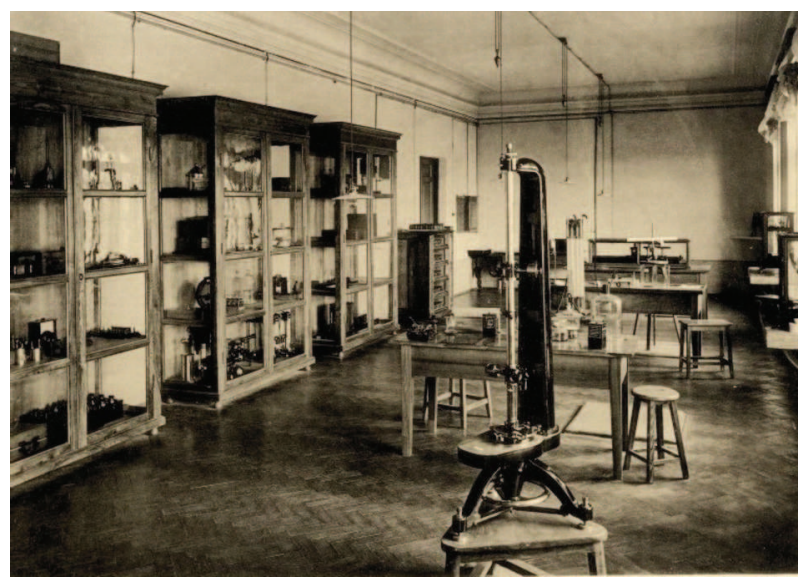

Photo 4. Laboratory of precise measurements, 1903

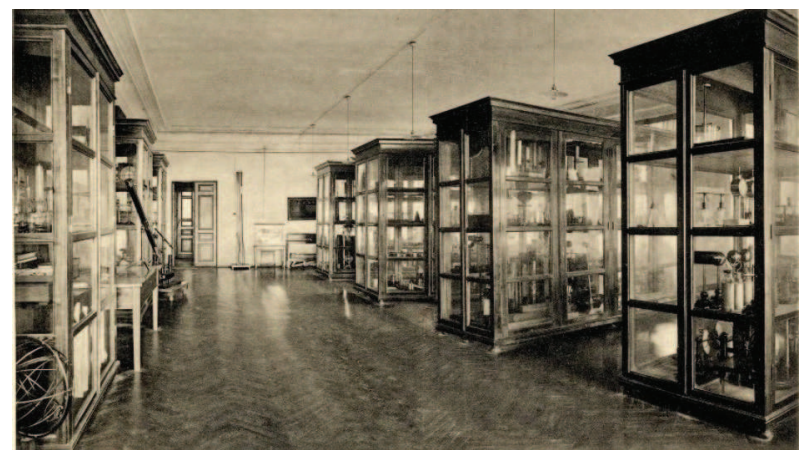

Photo 5. Museum of physical apparatus, 1903

to collect all the best from the equipment that he saw in foreign laboratories.

The big lecture-room located at the center between different rooms of the physical laboratory, had several separate entrances, 14 rows of seating and could seat at the same time 400-500 students. For evening classes, it had a new, at that time, electric lighting with 200 incandescent bulbs. At both sides of the blackboard were located the electric current switchers. In particular, the switchers for devices with a constant current of $250 \mathrm{~V}$ and three phases AC with zero conductor in $140 \mathrm{~V}$ between phase and zero [34]. The laboratory at the Kyiv Polytechnic Institute became one of the best in the Russian empire and, as compared with big institutions of Western Europe, had only smaller size, but not quality (Prof. G. DeMetz described the Physical Laboratory in his book whose cover is shown in Photo 3; see also Photo 4).

Thanks to the efforts of G. De-Metz, the Museum of the physical laboratory was created at KPI (see
Photo 5). The devices were located in sections: mechanical, sound, heat, light, and electric ones. Most apparatus were bought abroad in 1898 by the Professor. At the beginning of 1903 in the catalog of the laboratory, there were 1046 exhibits. So, here was the Foucault pendulum with optical readout produced by German firm Edelmann, a set of optical instruments for interference, diffraction, and light polarization produced by the French company Pellin. In addition, the laboratory had a full set of Geisler', Crooks', and Pulyui' tubes and other tubes for electrical discharges. Special value had the standards and precision measuring devices, namely, a chronograph produced by a Geneva company and a sugar meter produced by the company "Schmidt-Haentsch", a collection of thermometers to measure the temperature from $-200{ }^{\circ} \mathrm{C}$ to $+550{ }^{\circ} \mathrm{C}$, pyrometers by HartmanBraun standards, Latimer-Clark and Weston ones, as well as other equipment [35, p. 268].

From 1906, G. De-Metz became the editor of the popular science magazine "Physical Review". He held this position until 1917. Among his works on the promotion of physics published in this journal are the article "Hermann von Helmholtz (1821-1891)" [38], which provided the biographical information on the German scientist and discovered his 50-year scientific work, and "Century of the Metric System (17991899)" [37]. The article was one of the first works to discuss the development of the metric system. The author investigated the main stages of the formation of the International System of Units, analyzed the consequences of the introduction of new measures in different countries for the development of metrological support, scientific researches in theoretical metrology, and outlined the development of applied metrology on the base of technical educational institutions. This work should be considered as the first study on the history of metrology in Ukraine.

It should be noted that, in the period before the First World War, there were created all conditions for the exchange of scientific information among scientists. Leading scientists from institutes and universities traveled abroad to collect information, conduct experiments, procurement of equipment, etc., and constantly were aware of all the events that happened in the world scientific community. So, in AugustSeptember 1910 in Brussels was held the international Congress on radiology and electricity, which was visited by Professor G. De-Metz. Participants of 
the Congress were the leading scientists of the time, among them - M. Curie, A. Einstein, M. Planck and J. Perrin. They adopted a special resolution that the amount of Radium in radium consisted drugs should be measured by comparing the intensity of gamma radiation with radium that was the standard. The measurement result should be in milligram-equivalents of eadium. It was established the unit "Curie" $[17$, p. 11]. The participation of Professor G. De-Metz in this international event had confirmed his credibility among the scientific community. Thanks to the participation of the scientist in large-scale projects such as the international Congress was the active involvement of Ukrainian scientists in the world process of studies of X-rays and their application in practice. Similar to G. De-Metz experiments, the studies were performed by M. Pilchikov and O. Pohorelko at the Kharkiv Institute of Technology. In particular, O. Pohorelko made a report in the Kharkiv medical society, where he proved the practical value of a new phenomenon for medicine, i.e. the use of X-rays for the diagnosis. This report had a significant resonance in the city of Kharkiv. To the scientist began to bring patients to obtain X-ray images [39, p. 1261].

In 1913, the scientist was approved as Honorary Professor and, in 1915-1917, was the Dean of the Faculty of Physics and Mathematics of St. Volodymyr's University. In 1915, the military command, because of the threat of occupation of Kyiv, ordered the evacuation of the University "to the left bank of the Dnieper", which turned into an evacuation to Saratov.

At the beginning of 1916, G. De-Metz with other teachers of the University A. Kotelnikov and D. Grave actively participated in the work of the commission on the expansion of Saratov University, whicch resulted in the opening of the Faculty of Physics and Mathematics [40, p. 66]. From October 7 to November 28, 1917, G. De-Metz was temporarily acting as the Rector of St. Volodymyr's University.

On November 14, 1918, a landmark event for the Ukrainian history took place - Hetman P. Skoropadsky signed the Law on the founding of the Ukrainian Academy of Sciences in Kyiv. It was assumed that it would become the country's main scientific center and unite state research institutions. Professor G. De-Metz was assigned the Chairman of the Commission on Applied Physics [41, p. 6]. In 1918, the Department of Physical and Mathematical Sciences of the Ukrainian Academy of Sciences opened the third department of the Institute of Technical Physics Department of Metrology, where Professor Y. Kosonogov and Professor G. De-Metz planned to design the standards and instruments for the use in industry analogously to international prototypes, in particular, such as meter and kilogram [42].

From October 12, 1919, Professor G. De-Metz was elected the Rector of the Kyiv Polytechnic Institute. From October 16, 1919, Kyiv was under the authority of the Volunteer army led by A. Denikin [43]. In November, 1919, the Rector, to find the necessary funds to support scientific and academic life of the Institute, moved to Rostov-on-Don. From December 16, 1919, the city again came under the control of the Bolshevik regime. Through the constant warfare, Professor G. De-Metz was difficult to return immediately to Kyiv, so he decided to go through the Ekaterinodar (now Krasnodar). Here, he had to stay for some time; the scientist worked in a technical secondary school [17, p. 51].

In the spring of $1920, \mathrm{G}$. De-Metz taught a course in thermodynamics and radioactive substances at the Techno-Chemical Faculty of the Kuban Polytechnic Institute and, concurrently from May 1920 - "Course of physics" in the Working Polytechnic. In March 1920, Ekaterinodar city captured by Soviet authorities, and, in May 1920, Kyev city was occupied by the army of the Ukrainian People's Republic and Poland.

At the beginning of June 1920 through various circumstances, some progressive Ukrainian teachers came to Ekaterinodar. Among, the Rector of the Kharkiv University P. Pyatnitsky and the ViceRector T. Kravets, the Rector of the Kyiv Polytechnic Institute - G. De-Metz and the Rector of the Kharkiv Institute of Technology I. Krasouskij and the Professor of disbanded Samara University - O. Bagriy. In this initiative group of scientists conceived the idea of the possibility to open the Kuban University. On June 16, 1920, the resolution of the Kuban regional Department of education No. 17 was adopted in which Professor O. Bagriy had to form the Commission for the organization of the Kuban University. By secret ballot, the Professor G. De-Metz was elected a Chairman of the Natural History Department. In the short term, 1500 students were recruited. To organize the educational process with a significant number of students in cramped classrooms was extremely difficult. So sometimes, lectures were given just under the sky. When in late November was found a constant 
building, "the rector's crisis" arose. when the Rector N. Marx died from influenza. On his place was appointed the Dean of the Working Faculty B. Argunov, who, in two months, resigned his duties in favor of Professor G. De-Metz who was elected by the University Council [44, p. 237].

However, as further events testified, the University was doomed to destruction. The Bolshevik leadership was only interested in the Medical Faculty. From 1921, teachers began to return to their old universities. So, in the summer of 1921, O. Bagryi left, Professors G. De-Metz, V. Shaposhnikov, I. Krasouskij, and T. Kravets followed by him, as well as other teachers who had previously worked at the universities and institutes of Kyiv and Kharkiv.

By the first occasion in the early summer of 1921 , G. De-Metz returned to Kyiv, but couldn't get employment at the Kyiv Polytechnic Institute. Therefore, in August 1921, he began to work as a Professor at the Kyiv Institute of Public Education (KIPE). The Professor taught the physics methodology, organized students' classes at the physical cabinet, as well as prepared students for trial lessons before school pupils.

When the institutions of public education were created, it was found that there was a significant inconsistency in educational programs for the course of general physics. The structure of the discipline was defined by the lecturer. In particular, the original course, designed by G. De-Metz, studied the foundations of mechanics, experimental physics, and practical mechanics. Therefore, the curriculum of the Professor "General methods of teaching physics" in 1929 [45] was an important domestic achievement of the theory and methods of teaching physics in the period of innovation and creativity. It was the first methodical manual in the Ukrainian language, in which much attention was paid to the general questions of the methodology of physics teaching. In it, the author referred to the methodological issues of the didactics of physics as a pedagogical science, using domestic and foreign experiences in methodological research of the educational process in physics in the national high school. The author traced the proximity of contemporary European approaches to the physics learning, in which, during the study of physics, students learn to observe natural phenomena, to establish their main characteristics, gain knowledge about the methods of studying nature, and to form their sci- entific outlook. The author had identified the teaching of physics as the formation of students with true and clear ideas about the most important phenomena and laws of elementary physics, the relationship of these representations with the needs of life and modern technology. Among the examining methods of physics teaching, the experimental method of active educational-cognitive independent activity of students in the physical laboratory was put by Professor G. De-Metz on a prominent place. The author analyzed the possibility of "Dalton plan" in the teaching of physics in detail, which included bringing the school to life, contributed to instilling the sense of responsibility in students. An important feature in this case, emphasized by Professor G. De-Metz, was the fact that, for each, the teacher can work in three programs: maximum, medium, and minimum.

In general, it can be noted that the style of presentation of the material in G. De-Metz's methodology, its content and structure are close to modern teaching manuals, which provide a wide familiarization with different approaches, involving the pupil and the student to the active reflection, and was fundamentally different from the methodical manuals which were mentoring and ascertaining in nature. An important result of the Professor's scientific research was the creation of a list of laboratory works in physics for secondary schools and a list of necessary physical devices for the conducting of experiments.

In 1923, G. De-Metz was appointed as a Head of the Physical Institute of KIPE, and in the fall of that year was elected as a Comrade (Deputy) Chairman of the Physical and Mathematical Commission. In the fall of 1925, the scientist was elected as Head of the Physics and Mathematics Commission. In May 1926, G. De-Metz was summoned to Kharkiv to participate in training courses for teachers of higher education institutions. He was instructed to read three lectures on topics "About radioactivity", "About X-rays", and "About atomic structure".

In December 1926, during the 5th Congress of Russian Physicists in Moscow, a resolution was adopted on the establishment of the All-Union Association of Physicists. It should be mentioned, that the first elections of the Organizing Committee of the Ukrainian Association of Physicists (UAP) were also held. Professor G. De-Metz, Professors: O. Holdman (Kyiv), A. Zhelekhovskyi (Kharkiv), Ye. Kyrylov (Odessa), A. Malynovskyi (Dnepropetrovsk) became members 
of this association. In December 1927, in a letter to O. Holdman, Professor G. De-Metz informed that he had received letters from members of the Organizing Committee (A. Zhelekhovskyi, Ye. Kyrylov, A. Malinovskyi) in which they confirmed the "need to meet as soon as possible in Kharkiv" to resolve the issue of the Association's statute. As a result of UAP activities, the physical research in Ukraine has intensified [46, p. 179].

In 1926-1930, G. De-Metz worked at the Supply Academy (today the Kyiv National Economic University named after $\mathrm{V}$. Hetman) as a full professor, where he worked earlier as a part-time professor and taught physics [45, p. 2].

Despite all the achievements, since January 1, 1929, according to the law about the age limit of professors, G. De-Metz was fired from the KIPE with the appointment of a pension for years of service. As the professor himself noted, it was a conflict of interest with the Rector S. Semko. The scientist was accused of the underutilization of the Marxist-Leninist methodology, and his "great education" was considered a negative feature. The scientist was assigned a meager pension - 136 rubles 40 kopecks.

After his retirement from the KIPE, G. De-Metz received a number of invitations from various special institutions of higher education in Kyiv, including the Textile Institute, Mining and Geology, in which he worked as a professor in the departments of physics.

Since 1934, G. De-Metz worked as the head of the Department of Physics at the Kyiv Pedagogical Institute. In the same year, the Committee on Accounting and Study of the Scientific Forces of the USSR included his name into the Bibliographic Dictionary of prominent scientists of the USSR [47, p. 15].

At the same time, since 1935, the scientist worked as the Head of the Department of Physics at the Kyiv Chemical-Technological Institute. During the German occupation, Professor G. De-Metz stayed in Kyiv alone, his daughters were evacuated, and his wife died. When his eldest daughter returned to Kyiv, the professor was in a pitiful psychological state and almost did not recognize anyone. Professor G. DeMetz died on February 3, 1947. He was buried next to his wife at the Lukyanovsky Cemetery in Kyiv.

\section{Conclusion}

So, according to the analysis of the scientific work of Professor G. De-Metz, he really belongs to the leading scientists-physicists of Ukraine. Unfortunately, the figure of this outstanding scientist-innovator has not been adequately highlighted in the historical literature yet, not fully appreciated by the scientific community, the staff of scientific and educational institutions where this scientist worked. It was Professor G. De-Metz who continued to develop the achievements of European physical science in Ukraine. In spite of his considerable organizational work, he carried out many scientific researches, and stood at the origins of the methodology of teaching physics in Ukraine.

The authors have determined the importance of scientific and organizational, educational and promotional activities of G. De-Metz. The organizational activity of the scientist deserves special attention. He was actively involved in public projects, participated in the establishment of various scientific centers of the newly formed Ukrainian Academy of Sciences (Commission on Applied Physics, Department of Metrology, etc.). An important role was played by the scientist in the organization of the Ukrainian Association of Physicists. He was the author of the first UAP's statute. Professor G. DeMetz actively participated in the development of Ukrainian physical education. He worked as the Rector of Kyiv Polytechnic Institute and Kuban University and, for a short time, was the Rector of St. Volodymyr's University. He also participated in the work of many educational institutions of Kyiv. While working as a physics teacher at Kyiv Institute of Public Education, G. De-Metz paid attention to the methodology of physics teaching, focusing on the introduction of the latest pedagogical approaches.

Based on this, it is extremely important to study the scientific achievements of Ukrainian scientists. The study of their scientific heritage and experience of organizational activity contributes to the expansion of the horizon of knowledge of the laws of development of physical science, as well as the personification of the scientific and educational space of Ukraine by prominent figures.

The memory of Professor G. De-Metz is largely preserved due to his descendants.

The authors are grateful to the great-granddaughter of the scientist Katerina Shiplyuk (Klistorina) for providing materials from the family archive. 
1. Brokhaus and Efron Encyclopedic Dictionary. De Metz Georgy Georgievich (St. Petersburg, 1906) (in Russian).

2. Website of Taras Shevchenko National University of Kyiv. Retrieved July 31, 2019 from: http://univ.kiev.ua/en/ geninf/history-rectors/de-metts/.

3. Website of the National Technical University of Ukraine "Kyiv Polytechnic Institute". Retrieved August 2, 2019 from: https://kpi.ua/en/demetc.

4. Website of Vadim Hetman National Economic University of Kyiv. Retrieved July 31, 2019 from: https://kneu.edu.ua/en/University_en/about_university/ milest_of_hist/fam_teachers/.

5. O. Maìdebura, I. Güdkov. The outstanding physicist, organizer of higher education and science G. De-Metz - the first researcher in Ukraine of the effect of X-rays and natural radioactivity on living organisms. NUBiP Sci. Rep. 2012-4 33.

6. M. Golovko. Historical and methodological features of forming the content of the course of general physics of the higher school in Ukraine (XVII - beginning of XX centuries). Sci. J. of NP Dragomanov. Series 3. Phys. and Math. in high and high School 35 (2017).

7. A. Litvinko, L. Ponomarenko. International contacts of physicists of Ukraine with scientists of Western Europe in the XIX - early XX centuries. Questions of the history of science and technology No. 4, 29 (2016) (in Ukrainian).

8. D. Shilenko, E. Pisarenko, K. Udaltsova. Influence of the psychoemotional component and physiology of the visual organ on the reliable determination of tooth color characteristics in restoration dentists. Medical Medicine and Biology 4 (35), 48 (2012) (in Ukrainian).

9. L. Ponomarenko. Odessa period of becoming Professor G.G. De-Metz as a scientist and teacher (1881-1891). In: Modernization of scientific and technological policy of Ukraine: materials XXI All-Ukrainian conference. Apr 15 (Kyiv, 2016) (in Ukrainian).

10. L. Ponomarenko. The first teachers of physics in the KPI (to the 120th anniversary of the KPI). In: Proceedings of the XVII All-Ukrainian Scientific Conference "Topical issues of the history of science and technology" (Center for Monuments, 2018), P. 187 (in Ukrainian).

11. M. Gutnyk. Professor Georgi Georgievich De-Metz (18611947): biography (NTU "KhPI", 2019), P. 36 [ISBN: 978617-7771-86-8] (in Ukrainian).

12. G. De-Metz. Baron's Notes (1877).

13. G. De-Metz. Diary notes (1878).

14. G. De-Metz. Notes (1878).

15. G. Chelpanov. In a memory of Professor N. Grott. In: The Development of Science in Odessa I. Mechnikov National University (ONU, 2016).

16. State Archives of Odessa region. F. 45, Op. 4, Case 1857 (1884).

17. V. Savchuk. I.P. Pulyui apparatus for determining the mechanical equivalent of heat: history and modernity. In: International Scientific and Technical Conference "Ivan Pulyui: life in the name of science and Ukraine" (dedicated to the 175th anniversary of his birth) (September 28-30, 2020). Ternopil, 18-19 (in Ukrainian).

18. I.V. Korsun. Contribution of Ukrainian scientists to the development of optics. Ukr. J. Phys. 63, 10 (2018).

19. State Archives of Kyiv. De-Metz Georgy. F. 18, op. 2. Spr. 173.

20. VIII Congress of Russian Naturalists and Physicians in St. Petersburg from December 28, 1889 to January 7 (St. Petersburg, 1890).

21. State Archives of Odessa region. F. 45 Imperial Novorossiysk University, Op. 8. About changes in staff, Case 16 (1891).

22. G.V. Miroshnichenko. Influence of the activity of St. Volodymyr University of Kyiv on the development of education and science in the second half of the 19th century. Young Scientist 2 (17), 78 (2015) (in Ukrainian).

23. G.G. De-Metz. Modern views on electricity: An introduction. In: Lecture delivered on September 291892 in Imperial University of St. Vladimir (Kyiv, 1892).

24. G.G. De Metz. About the current state of color photography (Kyiv, 1893).

25. G.G. De-Metz. About Tesla experiments with alternating currents. V.O.F.E.M. 160 (1893).

26. G.G. De-Metz. Photography inside the Crookes Tube. J. Russ. Phys. Chem. Soc. at the Imperal St. Petersburg University. Part Physical 28 (3), 81 (1896).

27. G.G. De-Metz. The action of a magnet on X-rays. J. Russ. Phys. Soc. Part Physical 29 (9), 68 (1897).

28. G.G. De-Metz. X-rays of Rontgen and their field of application in medicine. J. Russ. Phys. Chem. Soc. at the Imperial St. Petersburg University. Part Physical 30 (2), 48 (1898).

29. G.G. De-Metz. The Doctrine on the Radioactivity and Radioactive Substances (State Committee for Statistics, 1905).

30. O.P. Maidebura. First radiobiological research in Ukraine Sumy Historical and Archival J. XVIII-XIX, 67 (2012).

31. Yu.A. Pasichnyk. Georgiy G. De-Metz: (To the 150th anniversary of the birth of Honored Professor of Physics). Scientific notes of NSU named after M. Gogol. Series: Psychological and Pedagogical Sciences 7, (2011) (in Ukrainian).

32. G.G. De-Metz. Radioactivity and Structure of Matter [Text]: manual for Physics and Social School Physics Teachers, 455 (Kharkiv - Kyiv, 1931).

33. Kyiv Polytechnic Institute. Essay on history. Edited by M. Zgurovsky (KPI, 1995).

34. Central State Historical Archives of Ukraine. F. 707, Op. 65, Case 1, 93. Announcement of the Rector of Kyiv University of October 15, 1899 on the appointment of professors V. Ermolov, S. Reformatsky, G. De-Metz as professors of the Kyiv Polytechnic Institute.

35. V. Mykolaenko. Creation of the Physical Laboratory. Kyiv Polytechnic No. 23 (2008).

36. G.G. De-Metz. Description of the Construction and Equipment of the Physical Laboratory at the Kyiv Polytechnic

ISSN 2071-0194. Ukr. J. Phys. 2021. Vol. 66, No. 9 
Institute of Emperor Alexander II (1898-1903) (Typography S.V. Kul'zhenko, 1903).

37. E.L. Khramova-Baranova. Metrological museum, its cultural aspects. In: History of Technology Museum: Materials of the VIII International Scientific and Practical Conference (December 2-4, 2014), Iss. 7 (Polytechnic Museum, Moscow, 2015).

38. G.G. De-Metz. Hermann von Helmholtz (1821-1891). Speech delivered at the solemn meeting of the Novorossiysk Society of Naturalists November 2, 1891. V.O.F.E.M. No. 128,157 ; No. 129,184 (1891).

39. G.G. De-Metz. The Century of the Metric System (17991899). A separate print of Physical Review 2, 28 (1901).

40. Description of the structure and equipment of the Physical Laboratory at the Kiev Polytechnic Institute of Emperor Alexander II. (1898-1903).

41. S. Radoguz, M. Gutnyk, R. Zaitsev, O. Tverytnykova The Development of Researches in the Electrical Engineering Field in Kharkiv Practical Technological Institute. The personalities. In: 2019 IEEE 2nd Ukraine Conference on Electrical and Computer Engineering (UKRCON). Conference proceedings (June 2-6, 2019, Lviv, Ukraine) (2019).

42. V.M. Anikin. Physics and Mathematics Faculty of Saratov University (1917-1945). News of Saratov University. Phys. Ser. 18, 1 (2018).

43. V.M. Loktev, L.P. Ponomarenko. To the history of academic physics research in Ukraine. Bulletin of the Nat. Acad. of Sci. of Ukraine 8, (2018).

44. E. Posvyatenko, O. Tverytnykova, N. Posvyatenko, T. Melnyk. Historical Affinity of Development of Applied Technical Sciences: Monograph (Kharkiv, 2017).

45. S. Mashkevich. Kiev under Fourteen Authorities. PART 2. Electronic resource.
46. A. Crymskiy. Notes of the Department of History and Philology. Anniversary Collection in Honor of Academician Dmitry Bagaliy on the Occasion of the Seventieth Anniversary of Life and the Fiftieth Anniversary of Scientific Activity; Kyiv, 192\%. Book. XIII-XIV (Typography of Ukr. Acad. Sci., 1927).

47. G.G. De-Metz. General Methodology of Teaching Physics: Theory and Practice of Teaching (Ukrderzhvydav., 1929).

48. M.A. Podrezova, V.V. Samodurova, E.S. Murashko. The Contribution of Physicists from Odessa (Novorossiysk) University to the Development of Science in Odessa. 19201933 [monograph]. Series: Development of science at the Odessa (Novorossiysk) University (Odessa, 2010) (in Russian).

49. T.I. Zaslavskaya. Selected publications. Vol. 3. My Life: Memories and Thinkings (Ekonomika, 2007) (in Russian).

Received 22.11.20

М.В. Гутник, О.Є. Тверитникова

ВНЕСОК ПРОФЕСОРА Г. ДЕ-МЕТЦА

У РОЗВИТОК ФІЗИЧНОЇ НАУКИ В УКРАЇНІ

На основі власних опрацювань щоденників Г.Г. Де-Метца, що зберігаються у праонуки вченого, спогадів онуки науковця та архівних матеріалів, наведено деякі моменти з особистого життя вченого, а також відомості про його наукову, педагогічну та організаційну діяльність. За своє життя вчений був ректором трьох закладів вищої освіти та очолював численні кафедри фізики. Розглянуто внесок Г.Г. Де-Метца у фізичні дослідження в Україні. Зокрема, висвітлено його популяризаторську діяльність щодо дослідів I. Пулюя, К. Рентгена, В. Крукса.

Ключов $і$ слов в: Георгій Де-Метц, фізична наука, Україна, рентген, медична фізика, методика викладання. 